\title{
Comparison of serum NEDD-9, CA 15-3, and CEA levels and PET metabolic parameters in breast cancer patients with 18 F-FDG PET / CT
}

\author{
Desra Arslan ${ }^{\mathbf{1}}$ \\ (iD) Hale Aral2 \\ (iD) Tamer Aksoy' \\ (D) Ciğdem Usul Afşar ${ }^{3}$ \\ (iD) Senem Karabulut ${ }^{4}$ \\ Fadime Didem Can Trabulus ${ }^{5}$ \\ (iD) Rıza Umar Gürsu ${ }^{6}$ \\ (D) Tevfik Fikret Çermik ${ }^{1}$
}

\begin{abstract}
1. University of Health and Sciences, Istanbul Training and Research Hospital, Department of Nuclear Medicine, Istanbul, Turkey.
2. University of Health and Sciences, Istanbul Training and Research Hospital, Department of Biochemistry, Istanbul, Turkey. 3. Acibadem Bakirkoy Hospital, Department of Internal Medicine and Medical Oncology, Medical Faculty, Acıbadem Mehmet Ali Aydınlar University, Istanbul, Turkey. 4. Department of Medical Oncology, Institute of Oncology, Istanbul University, Istanbul, Turkey.

5. University of Health and Sciences, Istanbul Training and Research Hospital, Department of Surgery, Istanbul, Turkey. 6. University of Health and Sciences, Istanbul Training and Research Hospital, Department of Medical Oncology, Istanbul, Turkey.
\end{abstract}

http://dx.doi.org/10.1590/1806-9282.66.5.673

\section{SUMMARY}

OBJECTIVE: Analyze the over expression of neural precursor cell expressed developmentally down-regulated protein 9 (NEDD-9) deregulated associated with a poor prognosis in various carcinomas. Our objective was to investigate the relationship between the levels of NEDD-9, CA 15-3, and CEA and PET (SUVmax, MTV40, TLG40) with the clinical parameters of patients with breast cancer (BC).

METHODS: One hundred and eleven patients (82 BC patients who underwent 18F-FDG PET/CT and 29 healthy controls) were evaluated. SUVmax, MTV, and TLG of the primary tumor were compared with the molecular and histopathological subtypes. 18F-FDG, MTV, and TLG were evaluated based on the clinical data, i.e., nodal involvement, distant metastasis, ER and PR status, Ki-67, serum levels of NEDD-9, CA15-3, and CEA. We compared the NEDD-9 in the BC and healthy control groups.

RESULTS: The mean \pm SD of SUVmax in the 82 patients was $13.0 \pm 8.6$. A statistically significant relationship $(p=0.022)$ was found between the molecular subtypes and 18F-FDG uptake. The relationship between 18F-FDG uptake and TLG measured in patients $<50$ years, ER-PR negativity, and HER2 positivity were statistically significant ( $p=0.015,0.007,0.046$, and 0.001, respectively). MTV40, TLG40, and CA 15-3 in metastatic patients were statistically significant ( $p=0.004,0.005$, and 0.003 , respectively). NEDD-9 in the BC group was significantly higher than in the healthy group ( $p=0.017$ ). There was a positive correlation between SUVmax and Ki67 and CA 15-3; MTV40 and CEA; CA 15-3, CEA, SUVmax, and MTV40; a negative correlation was found between CEA, TLG40, and age.

CONCLUSION: The use of SUVmax, MTV4O, and TLG40 parameters with NEDD-9 and tumor markers has been shown to provide a high diagnostic, predictive, and prognostic value for the management of $B C$. This is considered to be the basis of interventions focused on the treatment objectives related to NEDD-9.

KEYWORDS: Breast neoplasms. Fluorodeoxyglucose F18. Adaptor proteins, signal-transducing. Carcinoembryonic antigen.

DATE OF SUBMISSION: 09-Nov-2019

DATE OF ACCEPTANCE: 29-Dec-2019

CORRESPONDING AUTHOR: Esra Arslan

Istanbul Egitim ve Arastirma Hastanesi, Nukleer Tıp Kliniği, Org. Nafiz Gurman Caddesi, Samatya, Kocamustafapasa, Fatih, Istanbul, Turkey

Tel: +90 212 459-6455 / Fax: +90 $212632-6329$

E-mail: dresraarslan@gmail.com 


\section{INTRODUCTION}

The Cas protein family plays a role in the management of cell survival, proliferation, and migration. ${ }^{1}$ The "Neural precursor cell expressed developmental downregulated 9" (NEDD-9) initiates a process resulting in differentiation, proliferation, and migration by revealing the potential tumorigenesis of cells. ${ }^{2}$ NEDD-9 overexpression is associated with poor prognosis, shortened survival in breast carcinomas (BC) and many other types of cancer. NEDD-9 overexpression has been reported to be strongly correlated with cancer metastasis due to its regulatory property on cell migration. $^{3-5}$

Carcinoembryonic antigens (CEA) and carbohydrate antigens 15-3 (CA 15-3) are used in BC follow-up; however, their prognostic value is limited regarding its sensitivity and specificity. ${ }^{6}$ The American Society of Clinical Oncology does not recommend them for the diagnosis, screening, staging, and treatment follow-up of BC. ${ }^{78}$ F-fluoro-2-deoxyglucose positron emission tomography/computed tomography $\left({ }^{18} \mathrm{~F}-\mathrm{FDG}\right.$ PET/ $\mathrm{CT}$ ) is recommended for the staging, prognosis, and follow-up of BC. ${ }^{8}$ In several studies, the maximum standardized uptake (SUVmax) levels, tumor characteristics and total metabolic tumor volume (MTV), lesion glycolysis (TLG) have demonstrated potential prognostic value., ${ }^{\mathbf{9} 10}$

We aim to investigate the potential predictive, diagnostic, prognostic, and clinical value of NEDD-9, CA15-3, and CEA, along with PET parameters (SUVmax, MTV, TLG) in BC.

\section{METHODS}

\section{Patients}

We included eighty-two BC patients who underwent ${ }^{18}$ F-FDG PET/CT and 29 healthy subjects, with a total 111 subjects enrolled in this study. For our prospective study, the local ethics committee approval has obtained (2018/1380). Verbal and written informed consent was obtained from patients.

\section{Histological Analysis}

BC histopathological analysis was performed on tissue samples prior to ${ }^{18} \mathrm{~F}$-FDG PET/CT or breast-conserving surgery following ${ }^{18} \mathrm{~F}$-FDG PET/CT. The Scarff Bloom Richardson (SBR) classification system was used for staging. Receptors found positive for ER and PR showed $10 \%$ or more in immunohistochemical staining in positive tumor cells.
Scoring for HER2;

- Score 0: negative immunostaining,

- Score 1: poor staining/staining lesser than 30\%,

- Score 2: Uniform/complete membranous staining, even if weak staining,

- Score 3: Uniform staining of at least 30\%.

Cut-off value Ki-67 determined at $15 \%$ by using immunohistochemical and gene expression profiling methods for the differentiation of Luminal subtypes in routine practice and $<15 \%$ was considered low, and $\geq 15 \%$ high. $^{11}$

Molecular subgroups;

1. Luminal A: ER (+) and/or PR (+), HER2 (-) \& Low Ki-67 (<15\%),

2.Luminal B: ER $(+)$ and/or PR $(+)$, HER2 $(+)$, or HER2 (-) \& High Ki-67 ( $\geq 15 \%)$,

3.Triple negative/basal: ER (-), PR (-), HER2 (-),

4.HER2 Type: ER (-), PR (-), HER2 (+).

\section{F-FDG PET/CT Imaging}

Glucose levels lower than $150 \mathrm{mg} / \mathrm{dl}$ at least six hours of fasting were admitted. 3.7-5.3 MBq/ $/ \mathrm{kg}^{18} \mathrm{~F}$ FDG IV injection was administered. After 45 to 60 minutes after IV injection, imaging was obtained from the vertex-mid thigh (mCT 20 ultra HD LSO PET/CT, Siemens Molecular Imaging, Hoffmann Estates, Illinois, USA).

Maximum standard uptake (SUVmax) was calculated by "volume-of-interest (VOI)" on the most active-looking slice of ${ }^{18} \mathrm{~F}$-FDG positive lesions. SUVmax was calculated according to the formula: Maximum activity inside the ROI (MBq/gr), injected ${ }^{18} \mathrm{~F}$-FDG dosage (MBq/kg body mass). Metabolic tumor volume (MTV40) and tumor lesion glucose (TLG40) was calculated by the standard methods.

Based on the PET/CT parameters, histopathological-molecular characteristics, receptor properties, nodal involvement and distant metastasis, NEDD-9 was evaluated and reported along with CA15-3 and CEA. The NEDD-9 expression was compared between the $\mathrm{BC}$ and healthy control groups.

\section{Biochemical analysis}

CEA and CA 15-3 measured by electrochemiluminescence, Roche, Cobas 6000 model (Tokyo, Japan) immunological autoanalyzer system with chemiluminescent test kits. NEDD-9 expression obtained by enzyme-linked immunosorbent assay anti-NEDD-9 antibodies (INOVA, San Diego, Calif., USA). 


\section{Statistical analysis}

Data were analyzed by SPSS software (v21.0; IBM, Armonk, NY, USA). The normalization of data distribution was evaluated by the Kolmogorov-Smirnov test. The Mann Whitney and Kruskal Wallis tests were used for comparing the variables; the correlation analysis was evaluated by the Pearson test. The Chi-Square test was used to evaluate categorizable variables. Results were considered statistically significant when $\mathrm{P}<0.05$.

\section{RESULTS}

The Mean \pm SD age was $55.0 \pm 12.5$ years in the $\mathrm{BC}$ group, and $50.3 \pm 11.3$ years in the control group $(\mathrm{p}=$ 0.078). A total of $51.2 \%$ in the BC group and $44.8 \%$ in the control group were in the menopause period $(p$ $=0.554) .{ }^{18} \mathrm{~F}$-FDG uptake was observed in all tumors $(\mathrm{n}=82)$. The mean SUVmax was $13.0 \pm 8.6$ (median= 11.6 , range $=2.1-48.4$ ). The molecular subtype classification was as follows: 13 (15.9\%) identified luminal A; 50 (61.0\%) luminal B; 10 (12.2\%) triple-negative; and 9 (11.0\%) HER2 type. The relationship between ${ }^{18} \mathrm{~F}$-FDG uptake and molecular subtype classification was evaluated; the mean SUVmax in luminal A was $9.4 \pm 6.5$, $12.1 \pm 6.9$ in luminal $\mathrm{B}, 16.7 \pm 12.9$ in triple-negative, and $19.2 \pm 10.4$ in the HER2 type. A statistically significant relationship was found between the molecular subtypes and SUVmax $(p=0.022)$.

Invasive ductal carcinoma was in found $73.2 \%(\mathrm{n}=$ $60)$, invasive lobular carcinoma in $9.8 \%(\mathrm{n}=8)$, mucinous in $6.1 \%(\mathrm{n}=5)$, apocrine in $4.9 \%(\mathrm{n}=4)$, micropapillary in $3.7 \%(\mathrm{n}=3)$, neuroendocrine in $1.2 \%(\mathrm{n}=1)$, and mixed type in $1.2 \%(n=1)$. No statistically significant difference was found between histopathological types and ${ }^{18}$ F-FDG uptake.

The clinical features of patients were evaluated according to 18F-FDG uptake, MTV40, and TLG40. The mean \pm SD of TLG40 $(244.1 \pm 444.3)$ in the group below 50 years $(\mathrm{n}=32)$ was not found to be significantly higher than the mean \pm SD of TLG40 (122.3 \pm 276.5$)$ in those older than 50 years $(n=50)(p=0.015)$. A total of $76.8 \%(n=63)$ of tumors were $\mathrm{ER}(+), 61.0 \%(\mathrm{n}=50)$ were $\mathrm{PR}(+)$, and $20.7 \%(\mathrm{n}=17)$ were HER2(+). 18F-FDG uptake was associated with negative ER-PR and positive HER2; the association was statistically significant ( $\mathrm{p}=0.007,0.046$, and 0.001, respectively). Ki-67 expression was high $(\geq 15 \%)$ in 70 cases $(85.4 \%)$ and low $(<15 \%)$ in 12 cases $(14.6 \%)$. SUVmax, MTV, and TLG40 did not show any statistically significant difference compared to Ki-67 (Table 1).

A total of $65.9 \%$ of patients $(n=54)$ presented LN involvement but there was no correlation with

TABLE 1. MEAN $\pm S D$ SUVMAX, MTV4O, TLG40, NEDD-9, CA 15-3 AND CEA VALUES CHANGE ACCORDING TO THE CLINICAL AND HISTOPATHOLOGICAL CHARACTERISTICS OF THE PATIENTS

\begin{tabular}{|c|c|c|c|c|c|c|c|c|c|c|c|c|c|}
\hline & $n(\%)$ & $\begin{array}{l}\text { SUVmax } \\
(\text { Mean } \pm S D)\end{array}$ & $\mathrm{p}$-value & $\begin{array}{l}\text { MTV40 } \\
(\text { Mean } \pm S D)\end{array}$ & $\mathrm{p}$-value & $\begin{array}{l}\text { TLG40 } \\
(\text { Mean } \pm S D)\end{array}$ & p-value & $\begin{array}{l}\text { NEDD-9 } \\
(\mathrm{ng} / \mathrm{ml}) \\
(\text { Mean } \pm S D)\end{array}$ & $\mathrm{p}$-value & $\begin{array}{l}\text { CA } 15-3 \\
(\mathrm{U} / \mathrm{ml}) \\
(\text { Mean } \pm S D)\end{array}$ & p-value & $\begin{array}{l}\text { CEA } \\
(\mathrm{ng} / \mathrm{ml}) \\
(\text { Mean } \pm S D)\end{array}$ & $\mathrm{p}$-value \\
\hline \multicolumn{14}{|l|}{ Age } \\
\hline $\begin{array}{l}<50 \\
\geq 50\end{array}$ & $\begin{array}{l}32(39.0 \%) \\
50(61.0 \%)\end{array}$ & $\begin{array}{l}14.4 \pm 8.7 \\
12.2 \pm 8.4\end{array}$ & 0.201 & $\begin{array}{l}37.6 \pm 67.9 \\
14.7 \pm 17.8 \\
\end{array}$ & 0.126 & $\begin{array}{l}244.1 \pm 444.3 \\
122.3 \pm 276.5\end{array}$ & $0.015^{\star}$ & $\begin{array}{l}1.8 \pm 1.3 \\
2.2 \pm 1.9\end{array}$ & 0.467 & $\begin{array}{l}22.6 \pm 35.9 \\
22.1 \pm 23.2\end{array}$ & 0.618 & $\begin{array}{l}13.28 \pm 36.06 \\
5.18 \pm 16.22\end{array}$ & 0.768 \\
\hline \multicolumn{14}{|l|}{ ER } \\
\hline $\begin{array}{l}\text { Negative } \\
\text { Positive }\end{array}$ & $\begin{array}{l}19(23.2 \%) \\
63(76.8 \%)\end{array}$ & $\begin{array}{l}17.9 \pm 11.6 \\
11.6 \pm 6.9\end{array}$ & $0.007^{\star}$ & $\begin{array}{l}22.2 \pm 37.3 \\
24.0 \pm 48.1\end{array}$ & 0.725 & $\begin{array}{l}247.1 \pm 532.8 \\
146.6 \pm 281.1\end{array}$ & 0.054 & $\begin{array}{l}2.3 \pm 1.7 \\
2.0 \pm 1.7\end{array}$ & 0.323 & $\begin{array}{l}26.3 \pm 29.7 \\
21.1 \pm 28.4\end{array}$ & 0.302 & \begin{tabular}{|l}
$1.8 \pm 1.2$ \\
$10.3 \pm 29.3$
\end{tabular} & $0.031^{\star}$ \\
\hline \multicolumn{14}{|l|}{ PR } \\
\hline $\begin{array}{l}\text { Negative } \\
\text { Positive }\end{array}$ & $\begin{array}{l}32(39.0 \%) \\
50(61.0 \%)\end{array}$ & $\begin{array}{l}15.5 \pm 10.4 \\
11.5 \pm 6.8\end{array}$ & $0.046^{\star}$ & $\begin{array}{l}19.2 \pm 30.2 \\
26.5 \pm 53.4\end{array}$ & 0.736 & $\begin{array}{l}183.6 \pm 416.0 \\
161.1 \pm 312.4\end{array}$ & 0.151 & $\begin{array}{l}2.3 \pm 2.1 \\
1.9 \pm 1.4\end{array}$ & 0.714 & $\begin{array}{l}23.2 \pm 23.8 \\
21.7 \pm 31.5\end{array}$ & 0.172 & $\begin{array}{l}5.8 \pm 20.1 \\
9.9 \pm 29.2\end{array}$ & 0.084 \\
\hline \multicolumn{14}{|l|}{ HER2 } \\
\hline $\begin{array}{l}\text { Negative } \\
\text { Positive }\end{array}$ & $\begin{array}{l}65(79.3 \%) \\
17(20.7 \%)\end{array}$ & $\begin{array}{l}11.7 \pm 8.2 \\
18.0 \pm 8.4\end{array}$ & $0.001^{*}$ & $\begin{array}{l}25.2 \pm 49.9 \\
17.5 \pm 23.4\end{array}$ & 0.868 & $\begin{array}{l}166.0 \pm 383.2 \\
184.8 \pm 217.2\end{array}$ & 0.124 & $\begin{array}{l}2.1 \pm 1.8 \\
1.8 \pm 1.3\end{array}$ & 0.762 & $\begin{array}{l}20.5 \pm 21.0 \\
29.3 \pm 48.0\end{array}$ & 0.331 & \begin{tabular}{|l}
$5.5 \pm 15.1$ \\
$19.2 \pm 48.3$
\end{tabular} & 0.556 \\
\hline \multicolumn{14}{|l|}{$\mathrm{Ki}-67$} \\
\hline $\begin{array}{l}<15 \% \\
\geq 15 \%\end{array}$ & $\begin{array}{l}12(14.6 \%) \\
70(85.4 \%)\end{array}$ & $\begin{array}{l}9.7 \pm 7.2 \\
13.6 \pm 8.7\end{array}$ & 0.117 & $\begin{array}{l}18.6 \pm 19.2 \\
24.5 \pm 48.8\end{array}$ & 0.641 & $\begin{array}{l}135.2 \pm 163.4 \\
175.8 \pm 377.7\end{array}$ & 0.582 & $\begin{array}{l}1.6 \pm 1.3 \\
2.1 \pm 1.7\end{array}$ & 0.265 & $\begin{array}{l}25.3 \pm 25.0 \\
21.8 \pm 29.3\end{array}$ & 0.491 & $\begin{array}{l}15.1 \pm 33.4 \\
7.2 \pm 24.5\end{array}$ & 0.546 \\
\hline \multicolumn{14}{|c|}{ Nodal involvement } \\
\hline $\begin{array}{l}\text { Absent } \\
\text { Present }\end{array}$ & $\begin{array}{l}28(34.1 \%) \\
54(65.9 \%)\end{array}$ & $\begin{array}{l}11.3 \pm 5.5 \\
14.0 \pm 9.7\end{array}$ & 0.423 & $\begin{array}{l}14.9 \pm 14.6 \\
28.1 \pm 54.9\end{array}$ & 0.766 & \begin{tabular}{|l|}
$112.6 \pm 121.5$ \\
$199.5 \pm 426.0$
\end{tabular} & 0.571 & $\begin{array}{l}2.3 \pm 2.0 \\
1.9 \pm 1.5\end{array}$ & 0.363 & $\begin{array}{l}20.3 \pm 18.9 \\
23.3 \pm 32.6\end{array}$ & 0.938 & $\begin{array}{l}4.2 \pm 7.5 \\
10.5 \pm 31.4\end{array}$ & 0.880 \\
\hline \multicolumn{14}{|c|}{ Organ metastasis } \\
\hline $\begin{array}{l}\text { Absent } \\
\text { Present }\end{array}$ & $\begin{array}{l}55(67.1 \%) \\
14(17.1 \%)\end{array}$ & $\begin{array}{l}12.8 \pm 8.8 \\
16.3 \pm 9.7\end{array}$ & 0.148 & \begin{tabular}{|l|}
$18.1 \pm 40.7$ \\
$53.2 \pm 69.7$
\end{tabular} & $0.004^{*}$ & $\begin{array}{l}100.5 \pm 125.1 \\
504.1 \pm 749.6\end{array}$ & $0.005^{\star}$ & $\begin{array}{l}2.2 \pm 1.8 \\
1.5 \pm 1.3\end{array}$ & 0.152 & $\begin{array}{l}17.9 \pm 17.7 \\
41.3 \pm 54.1\end{array}$ & $0.003^{*}$ & $\begin{array}{l}3.3 \pm 5.6 \\
25.5 \pm 52.2\end{array}$ & $0.052^{\star}$ \\
\hline
\end{tabular}

${ }^{*}=p<0.05$ statistically significant. 
SUVmax, MTV40, and TLG40 (Table 1). Distant metastasis detected in 14 cases $(17 \%)$. In $13.4 \%(n=11)$ there was bone-bone marrow metastasis (Figure 1), in 1.2\% $(\mathrm{n}=1)$ multiple variable metastasis, in $1.2 \%(\mathrm{n}=1)$ liver, and in $1.2 \%(n=1)$ lung. No statistically significant difference was found $(p=0.148)$ in SUVmax between groups with/without distant metastasis; MTV40 and TLG40 in patients with distant metastasis were significantly higher than in those without it ( $p$-values= 0.004 and 0.005 , respectively) (Table1). The mean serum NEDD-9 was $2.05 \pm 1.69 \mathrm{ng} / \mathrm{ml}$ in $\mathrm{BC}$ and 1.44 $\pm 0.88 \mathrm{ng} / \mathrm{ml}$ in healthy controls. NEDD-9 was significantly higher in BC compared to the healthy controls $(p=0.017)$. The clinical features of BC were evaluated according to the NEDD-9, CA 15-3, and CEA values; no statistically significant relationship between NEDD-9 and receptor status (ER, PR, HER2), Ki67, LN, or distant metastasis was found ( $p>0.05)$. CA 15-3 in metastatic BC was found to be statistically significantly higher than in those without organ metastasis $(\mathrm{p}=$ 0.003) (Table 1).

The correlations between SUVmax, MTV40, and TLG40 and NEDD-9, CA 15-3, and CEA are presented in Table 2. There was a statistically significant correlation between SUVmax and Ki-67, CA 15-3, and a negative correlation between SUVmax and CEA. A statistically significant correlation was found between MTV40 and CEA. A statistically significant negative correlation was found between TLG40 and mean age, and a positive correlation between CA 15-3, CEA, SUVmax, and MTV.

\section{DISCUSSION}

The oncogenic characteristics associated with NEDD-9 have been highlighted in many studies. The metastatic inducing effect of NEDD-9 is present in many cancers, including BC. ${ }^{12,13}{ }^{18} \mathrm{~F}^{-}$FDG PET/CT has been shown to provide useful $\mathrm{BC}$ staging and follow-up. In BC, there are limited data regarding the combination of NEDD-9, PET/CT parameters for combined diagnostic and prognostic potentials. Ueda et al. ${ }^{14}$ evaluated $152 \mathrm{BC}$ cases preoperatively with ${ }^{18}$ F-FDG PET/CT; they analyzed high SUVmax with tumor size, grade, nuclear type, LN metastasis, histopathological subtype, negative ER - PR and positive HER2 expression and their statistically significant correlation with poor prognosis in BC. Studies have shown ${ }^{18} \mathrm{~F}$-FDG uptake in BC might be statistically different according to the histopathological subtype, molecular grading, ER - PR receptor expression, LN involvement, and distant metastasis. ${ }^{18}$ F-FDG PET/CT provides insufficient benefits, especially in LN and distant organ metastasis. ${ }^{8,15}$ A meta-analysis of 23 studies

FIGURE 1. 53 YEARS OLD F, LEFT BREAST LOCALISED ER(-),PR(-),HER2(-) TRIPLE NEGATIVE (LUMINAL C) INVASIVE DUCTAL TYPE CARCINOMA (PET: POSITRON EMISSION TOMOGRAPHY, CT: COMPUTED TOMOGRAPHY, F: FUSION, MIP: MAXIMUM INTENSITY PROJECTION), KI 67: 50\%, PRIMARY TUMOR AXIAL DIAMETER: $2.61 \mathrm{~cm}$, PRIMARY TUMOR SUV MAX: 9.24, PRIMARY TUMOR SUVMEAN: 5.41, PRIMARY TUMOR MTV4O(\%): 6.62, TLG40: 35.8, AXILLARY LN METASTASIS(+),BONE METASTASIS(+), SERUM NEDD 9 LEVEL: 6.954 ng/ml,SERUM CA15.3 LEVEL:69.8 (U/ml), SERUM CEA LEVEL:2.59 (ng/ml).

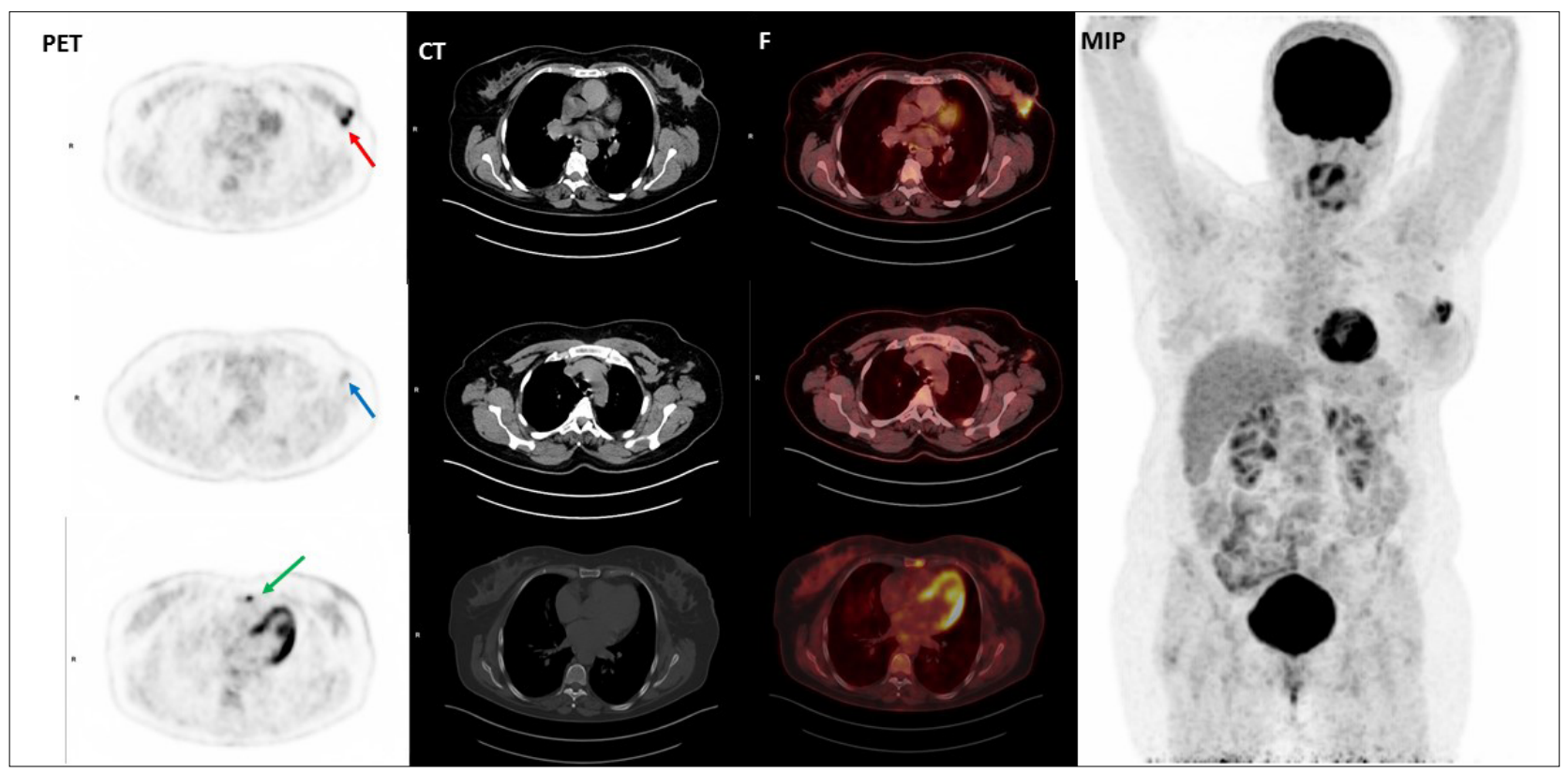


published by Liu et al. ${ }^{15}$ concluded that the ${ }^{18}$ F-FDG PET/CT method has low metastatic sensitivity but high specificity, whereas conventional methods such as MRI were more effective in detecting metastasis. Robertson et al. ${ }^{16}$ emphasized that 18F-FDG uptake has very low sensitivity for $\mathrm{LN}$ detection.

In our study, statistically significant differences were found between the molecular subtypes and SUVmax, and ER - PR negativity, HER2 positivity, and increased 18F-FDG uptake were significantly correlated. However, we did not find statistical significance in SUVmax between non-metastatic and LN involvement/distant metastatic BC.

MTV and TLG parameters from ${ }^{18} \mathrm{~F}$-FDG PET/CT provide information not only on the severity of $18 \mathrm{~F}$ FDG uptake but the volume and metabolic activity of the tumor. Son et al. ${ }^{17}$ concluded that MTV is a useful prognostic factor for metastatic BC. Marinelli et al. ${ }^{18}$ found the MTV of 47 triple-negative BC (TNBC) patients, MTV is a strong prognostic factor for TNBC. Based on the study of 135 IDC patients, Yoo et al. ${ }^{19}$ concluded that TLG is predictive of ALN metastasis. Based on 85 BC patients, Koizumi et al. ${ }^{20}$ reported that TLG is predictive of bone metastasis detection. In our study, we did not find any statistical correlation between SUVmax and distant organ metastasis; but the MTV40 and TLG40 calculated in distant metastatic patients were significantly higher than those without metastasis.
NEDD-9 overexpression revealed a complex signaling mechanism that provides a basis for migration, invasion, morphological transformation and proliferation, number of aggressive tumor characteristics, and metastasis-related studies in different tumors. ${ }^{3,4}$ Kong et al. ${ }^{5}$ noted that NEDD-9 expression was increased in TNBC patients. Štajduhar et al..$^{21}$ showed, based on 40 non-metastatic tissue samples and 40 metastatic samples from BC, increased NEDD-9 expression in ALN metastasis. Hata et al. ${ }^{22}$ reported a high NEDD-9 expression in bone metastatic BC. Loskutov et al. ${ }^{23}$ noted that NEDD-9 inhibition significantly reduced tumor growth and metastasis in BC xenograft models. In a meta-analysis of 13 studies, 1179 cases and 493 controls, Fu and $\mathrm{Li}^{24}$ concluded that CA15-3 and CEA are potential markers for BC and can be used for tumor staging and follow-up. In many published data, these were reported to be beneficial in poor prognosis, metastasis, and treatment follow-up. ${ }^{25}$ In our study, NEDD-9 was found to be statistically significantly higher in BC compared to healthy controls. The CA 15-3 of a distant metastatic group was significantly higher than in one without metastasis. A statistically significant positive correlation was found between SUVmax and CA 15-3; a negative correlation was found between CEA and SUVmax. A statistically significant correlation was found between MTV and CEA. A statistically significant correlation was found between TLG and CA 15-3, CEA, SUVmax, and MTV.

TABLE 2. CORRELATION ANALYSIS AMONG WITH CLINICAL, PATHOLOGICAL, BIOCHEMICAL FEATURES AND PET PARAMETERS IN PATIENTS GROUP

\begin{tabular}{|c|c|c|c|c|c|c|}
\hline & SUVmax & MTV40 & TLG40 & & & \\
\hline & $r$ & $p$ & $\mathrm{R}$ & $p$ & $\mathrm{R}$ & $P$ \\
\hline \multicolumn{7}{|l|}{ Age } \\
\hline & -0.169 & 0.128 & -0.120 & 0.282 & -0.227 & $0.040^{*}$ \\
\hline \multicolumn{7}{|c|}{ LN diameter } \\
\hline & 0.059 & 0.676 & 0.140 & 0.317 & 0.185 & 0.185 \\
\hline \multicolumn{7}{|l|}{$\mathrm{Ki}-67$} \\
\hline & 0.285 & $0.010^{*}$ & -0.009 & 0.937 & 0.154 & 0.168 \\
\hline \multicolumn{7}{|l|}{ NEDD-9 } \\
\hline & -0.020 & 0.859 & -0.127 & 0.255 & -0.141 & 0.206 \\
\hline \multicolumn{7}{|l|}{ CA 15-3 } \\
\hline & 0.299 & $0.006^{*}$ & 0.200 & 0.071 & 0.321 & $0.003^{*}$ \\
\hline \multicolumn{7}{|l|}{ CEA } \\
\hline & -0.021 & 0.849 & 0.301 & $0.006^{*}$ & 0.281 & $0.010^{*}$ \\
\hline \multicolumn{7}{|l|}{ SUVmax } \\
\hline & - & - & 0.128 & 0.250 & 0.512 & $0.000^{*}$ \\
\hline \multicolumn{7}{|l|}{ MTV40 } \\
\hline & - & - & - & - & 0.853 & $0.000^{*}$ \\
\hline
\end{tabular}

${ }^{*}=p<0.05$ statistically significant. 
Increases in NEDD-9 expression in BC and SUVmax are due to significant changes in molecular subtypes and receptor status; the relationship between metastasis and MTV40 and TLG40, using NEDD-9 and ${ }^{18}$ F-FDG PET/CT metabolic parameters together, can contribute to BC staging. The correlation of CA 15-3 and CEA with ${ }^{18} \mathrm{~F}$-FDG PET/CT metabolic parameters may provide diagnostic, predictive, and prognostic value. We conclude that the use of SUVmax, MTV40, and TLG4O in combination with NEDD-9 and tumor markers will enhance $\mathrm{BC}$ management and provide a basis for NEDD-9-related treatment and target-oriented interventions.

\section{Conflicts of interest \\ None.}

Funding sources

None.

Author contribution form

\begin{tabular}{|c|c|c|c|c|c|c|c|c|}
\hline & Esra Arslan & Hale Aral & $\begin{array}{l}\text { Tamer } \\
\text { Aksoy }\end{array}$ & $\begin{array}{l}\text { Çiğdem } \\
\text { Usul Afsar }\end{array}$ & $\begin{array}{l}\text { Senem } \\
\text { Karabulut }\end{array}$ & $\begin{array}{l}\text { Fadime } \\
\text { Didem Can } \\
\text { Trabulus }\end{array}$ & $\begin{array}{l}\text { Riza Umar } \\
\text { Gursu }\end{array}$ & $\begin{array}{l}\text { Tevfik } \\
\text { Fikret } \\
\text { Cermik }\end{array}$ \\
\hline Idea/concept & $40 \%$ & $20 \%$ & $10 \%$ & $5 \%$ & $5 \%$ & $5 \%$ & $5 \%$ & $10 \%$ \\
\hline Design & $30 \%$ & $30 \%$ & $10 \%$ & $5 \%$ & $5 \%$ & $5 \%$ & $5 \%$ & $10 \%$ \\
\hline Check & $20 \%$ & $20 \%$ & $20 \%$ & $5 \%$ & $5 \%$ & $5 \%$ & $5 \%$ & $20 \%$ \\
\hline $\begin{array}{l}\text { Source and fund } \\
\text { providing }\end{array}$ & $30 \%$ & $30 \%$ & $10 \%$ & $5 \%$ & $5 \%$ & $5 \%$ & $5 \%$ & $10 \%$ \\
\hline $\begin{array}{l}\text { Data collecting and/or } \\
\text { processing }\end{array}$ & $30 \%$ & $20 \%$ & $20 \%$ & $5 \%$ & $5 \%$ & $5 \%$ & $5 \%$ & $10 \%$ \\
\hline Analysis-comment & $30 \%$ & $30 \%$ & $10 \%$ & $5 \%$ & $5 \%$ & $5 \%$ & $5 \%$ & $10 \%$ \\
\hline Literature screening & $20 \%$ & $20 \%$ & $20 \%$ & $5 \%$ & $5 \%$ & $5 \%$ & $5 \%$ & $20 \%$ \\
\hline Article writing & $60 \%$ & $10 \%$ & $5 \%$ & $5 \%$ & $5 \%$ & $5 \%$ & $5 \%$ & $5 \%$ \\
\hline Critical examination & $20 \%$ & $10 \%$ & $10 \%$ & $10 \%$ & $10 \%$ & $5 \%$ & $5 \%$ & $30 \%$ \\
\hline
\end{tabular}

\section{RESUMO}

OBJETIVO: Analisar a associação da superrexpressão das células NEDD-9 ao prognóstico negativo em vários tipos de carcinoma. Nosso objetivo foi investigar a relação entre os níveis de NEDD-9, CA 15-3 e CEA e PET (SUVmax, MTV40, TLG) e os parâmetros clínicos em pacientes com câncer de mama (CM).

MÉTOdos: Cento e onze pacientes (82 pacientes de CM submetidos a 18F-FDG PET/TC e 29 controles saudáveis) foram avaliados. SUVmax, MTV, e TLG do tumor primário foram comparados nos subtipos molecular e histopatológico. A captação de 18F-FDG, MTV, e TLG foi avaliada com base em dados clínicos (envolvimento nodal, metástase distante, status de ER e PR, Ki-67, níveis séricos de NEDD-9, CA15-3 e (EA). Foi comparada a NEDD-9 do grupo de CM e o controle saudável.

RESULTADOS: A média \pm DP de SUVmax de 82 pacientes foi de 13,0 $\pm 8,6$. Uma relação estatisticamente significativa $(p=0,022)$ foi encontrada entre subtipos moleculares e captação de 18F-FDG. A relação entre captação de 18F-FDG e TLG medida em pacientes com idade $<50$ anos, ER-PR negativo e HER2 positivo foi estatisticamente significativa ( $p=0,015 ; 0,007 ; 0,046 ;$ e 0,001, respectivamente). MTV40, TLG40 e CA 15-3 em pacientes metastáticos foram estatisticamente significantes ( $p=0,004,0,005$ e 0,003, respectivamente). NEDD-9 no grupo BC foi significativamente maior do que no grupo saudável ( $p=0,017)$. Uma correlação positiva foi encontrada entre SUVmax e Ki67 e CA 15-3; MTV40 e CEA; CA 15-3, CEA, SUVmax e MTV40; uma correlação negativa foi encontrada entre CEA, TLG40 e idade.

CONCLUSÃO: O uso dos parâmetros SUVmax, MTV4O e TLG40 com NEDD-9 e marcadores tumorais demonstrou um alto valor diagnóstico, preditivo e prognóstico para o manejo do CM. Isso é considerado a base para intervenções focadas nos objetivos de tratamento relacionados às NEDD9.

KEYWORDS: Neoplasias da mama. Fluorodesoxiglicose F18. Proteínas adaptadoras, transdutoras de sinal. Antígeno carcinoembrionário. 


\section{REFERENCES}

1. Tornillo G, Defilippi P, Cabodi S. Cas proteins: dodgy scaffolding in breast cancer. Breast Cancer Res. 2014;16(5):443.

2. Shagisultanova E, Gaponova AV, Gabbasov R, Nicolas E, Golemis EA. Preclinical and clinical studies of the NEDD9 scaffold protein in cancer and other diseases. Gene. 2015;567(1):1-11.

3. Kozyreva VK, McLaughlin SL, Livengood RH, Calkins RA, Kelley LC, Rajulapati $A$, et al. NEDD9 regulates actin dynamics through cortactin deacetylation in an AURKA/HDAC6-dependent manner. Mol Cancer Res. 2014;12(5):681-93.

4. Afsar CU, Karabulut M, Karabulut S, Ozal ST, Cikot M, Serilmez M, et al. Clinical significance of serum NEDD9 levels in patients with pancreatic cancer. Biomolecules. 2018;8(4). doi: 10.3390/biom8040169.

5. Kong C, Wang C, Wang L, Ma M, Niu C, Sun X, et al. NEDD9 is a positive regulator of epithelial-mesenchymal transition and promotes invasion in aggressive breast cancer. PloS One. 2011;6(7):e22666.

6. Geng B, Liang MM, Ye XB, Zhao WY. Association of CA 15-3 and CEA with clinicopathological parameters in patients with metastatic breast cancer. Mol Clin Oncol. 2015;3(1):232-6.

7. Harris L, Fritsche H, Mennel R, Norton L, Ravdin P, Taube S, et al. American Society of Clinical Oncology 2007: update of recommendations for the use of tumor markers in breast cancer. | Clin Oncol. 2007;25(33):5287-312.

8. Arslan E, Çermik TF, Trabulus FDC, Talu ECK, Başaran Ş. Role of 18F-FDG $\mathrm{PET} / \mathrm{CT}$ in evaluating molecular subtypes and clinicopathological features of primary breast cancer. Nucl Med Commun. 2018;39(7):680-90.

9. Arslan E, Aksoy T, Cermik T. The prognostic value of 18 FDG PET/CT metabolic tumor volume (MTV) in distant metastatic breast cancer. J Nucl Med. 2019;60(suppl. 1):1235.

10. Chen W, Zhu L, Yu X, Fu Q, Xu W, Wang P. Quantitative assessment of metabolic tumor burden in molecular subtypes of primary breast cancer with FDG PET/CT. Diagn Interv Radiol. 2018;24(6):336-41.

11. Cheang MC, Chia SK, Voduc D, Gao D, Leung S, Snider |, et al. Ki-67 index, HER2 status, and prognosis of patients with luminal B breast cancer. J Natl Cancer Inst. 2009;101(10):736-50.

12. lida J, Dorchak J, Slavik J, Clancy R, Cutler ML, Shriver CD. NEDD9 promotes breast cancer metastasis by regulating mitochondrial functions. 2016 San Antonio Breast Cancer Symposium; December 6-10, 2016; San Antonio, Texas.

13. Gu Y, Lu J, Chen C, Zheng F. NEDD9 overexpression predicts poor prognosis in solid cancers: a meta-analysis. OncoTargets Ther. 2019;12:4213-22.

14. Ueda S, Tsuda H, Asakawa H, Shigekawa T, Fukatsu K, Kondo N, et al. Clinicopathological and prognostic relevance of uptake level using
18F-fluorodeoxyglucose positron emission tomography/computed tomography fusion imaging (18F-FDG PET/CT) in primary breast cancer. Jpn J Clin Oncol. 2008;38(4):250-8.

15. Liu T, Cheng T, Xu W, Yan WL, Liu J, Yang HL. A meta-analysis of 18 FDGPET, MRI and bone scintigraphy for diagnosis of bone metastases in patients with breast cancer. Skeletal Radiol. 2011;40(5):523-31.

16. Robertson IJ, Hand F, Kell MR. FDG-PET/CT in the staging of local/regional metastases in breast cancer. Breast. 2011;20(6):491-4

17. Son SH, Lee SW, Jeong SY, Song BI, Chae YS, Ahn BC, et al. Whole-body metabolic tumor volume, as determined by (18)F-FDG PET/CT, as a prognostic factor of outcome for patients with breast cancer who have distant metastasis. AJR Am J Roentgenol. 2015;205(4):878-85.

18. Marinelli B, Espinet-Col C, Ulaner GA, McArthur HL, Gonen M, Jochelson $M$, et al. Prognostic value of FDG PET/CT-based metabolic tumor volumes in metastatic triple negative breast cancer patients. Am J Nucl Med Mol Imaging. 2016;6(2):120-7.

19. Yoo J, Kim BS, Yoon HJ. Predictive value of primary tumor parameters using 18 F-FDG PET/CT for occult lymph node metastasis in breast cancer with clinically negative axillary lymph node. Ann Nucl Med. 2018;32(9):642-8.

20. Koizumi M, Motegi K, Umeda T. A novel biomarker, active whole skeletal total lesion glycolysis (WS-TLG), as a quantitative method to measure bone metastatic activity in breast cancer patients. Ann Nucl Med. 2019;33(7):502-11.

21. Štajduhar E, Sedić $M$, Leniček T, Radulović $P$, Kerenji A, Krušlin $B$, et al. Expression of growth hormone receptor, plakoglobin and NEDD9 protein in association with tumour progression and metastasis in human breast cancer. Tumor Biol. 2014;35(7):6425-34.

22. Hata K, Morita Y, Nakanishi M, Nishisyou T, Yoneda T. TGF $\beta$ target gene NEDD9 identified by gene profiling plays a critical role in breast cancer bone metastasis. Bone. 2011;48(1):S13.

23. Loskutov YV, Kozyulina PY, Kozyreva VK, Ice RJ, Jones BC, Roston T], et al. NEDD9/Arf6-dependent endocytic trafficking of matrix metalloproteinase 14: a novel mechanism for blocking mesenchymal cell invasion and metastasis of breast cancer. Oncogene. 2015;34(28):3662-75.

24. Fu Y, Li H. Assessing clinical significance of serum CA15-3 and carcinoembryonic antigen (CEA) levels in breast cancer patients: a meta-analysis. Med Sci Monit. 2016:22:3154-62.

25. Lee JS, Park S, Park JM, Cho JH, Kim SI, Park BW. Elevated levels of preoperative CA 15-3 and CEA serum levels have independently poor prognostic significance in breast cancer. Ann Oncol. 2013;24(5):1225-31. 